\title{
Prospective View of Professional Study of Specialists in Physical Education and Sports in Higher Educational Universities of Ukraine (Based on the American Experience)
}

\author{
Serhii Medynskii \\ Doctor of Pedagogical Sciences, Professor, Lviv State University of Physical Culture \\ (Lviv, Ukraine) \\ E-mail: sermedyn@ukr.net \\ ORCID: 0000-0001-6082-6566

\section{Svitlana Shandruk} \\ Doctor of Pedagogical Sciences, Professor, \\ Volodymyr Vynnychenko Central Ukrainian State Pedagogical University \\ (Kropyvnytskyi, Ukraine) \\ E-mail: sishandruk@ukr.net \\ ORCID: 0000-0002-7472-4584
}

\author{
Svitlana Sovgira \\ Doctor of Pedagogical Sciences, Professor, \\ Pavlo Tychyna Uman State Pedagogical University \\ (Uman, Ukraine) \\ E-mail: sovgirasvitlana@gmail.com \\ ORCID: 0000-0002-8742-7773
}

\begin{abstract}
The article deals with the comparative and pedagogical analysis of organization of professional study of specialists in physical education and sports in the system of higher education in the United States of America, and to substantiate a possibility of creative use of the ideas of American experience in modernisation process of preparation of sports and physical culture specialists in Ukraine. 184 instructors of Ukrainian higher education establishments were interviewed in order to determine perspective directions of implementation of American experience of professional preparation of specialists in physical education and sports in Ukraine. Survey on modernization of professional study of specialists in physical education and sports was based on practicability of implementation of American experience received in the universities of the USA. The qualifying experiment determined Ukrainian higher education
\end{abstract}

\footnotetext{
(C) Medynskii, Serhii, 2018

(C) Shandruk, Svitlana, 2018

(C) Sovgira, Svitlana, 2018
} 
instructors' level of perception of the components of practical organization of educational process at the US universities and substantiated a possibility of creative use of the ideas of American experience in modernisation process of preparation of sports and physical culture specialists in Ukraine.

Keywords: physical education, higher education, sports, modernization, professional study, American experience.

Received: June 10, 2018; accepted: September 12, 2018

Future Human Image, Volume 10, 2018: 50-61.

DOI: $10.29202 / \mathrm{fhi} / 10 / 5$

\section{Introduction}

Physical education and sports in Ukraine are recognised as the sphere of functioning of civil society and socio-humanitarian policy of the state. Social significance and priority of physical education and sports in Ukraine is declared in the laws of Ukraine "On Education" [Zakon Ukraiiny Pro Osvitu, 2017], “On Physical Education and Sports” [Zakon Ukraiiny Pro fizychnu kulturu, 1994], State National Program "Education” (Ukraine 21st Century) [Derzhavna natsionalna, 1993], National Strategy of the Development of Education in Ukraine [Natsionalna strategiya rozvytku, 2013]. The National Strategy for Motor Rehabilitation in Ukraine up to 2025 "Motor activity — healthy lifestyle — healthy nation" [Natsionalna strategiya, 2016] declares that the state's goal is to create conditions for raising the level of involvement of the population in improving motor activity and healthy lifestyle to form the health of citizens as the highest social value of the state in order to solve humanitarian and socioeconomic problems of a person, the society and the state.

Development of physical education and sports in Ukraine is characterized by tense situation in staff assistance marked by imbalance between training capacity and real needs in specialists in physical education and sports; irrelevance of content of their preparation from real needs and time demands. Today there is no need in a specialist-performer or an expert in sports work, today a competent specialist-organizer, initiator of motor activity improvement as the main factor of prevention of chronic non-infectious diseases and providing healthy lifestyle, a specialist in recreation and rehabilitation, a manager who is well-informed with the regulatory framework in the field of physical education and sports, equipped with adequate professional knowledge and technologies of physical culture, recreation and sports activities is needed.

The meanings of the theory of education upon which the theory is built, and which it generates, are much broader than the ideas of transhumanism, philosophical posthumanism and cosmism. They reveal the ontological cosmic nature of man; give the possibility of the ascent from the understanding of "I" as self, toward the understanding of oneself as that who transform the Universe for good of future generations. It is an opportunity to acquire a single philosophy of knowledge, the meaning of human life and the cultural ideal for the Earth civilisation. This is the genesis of the idea of man transforming the Universe [Bazaluk, 2017].

Ukrainian scientist Natalia Boychenko outline a common vision of certain range of ethical values but should also provide value-ethical means to achieve the educational goals; counterfactually legitimated factual goals and means would provide higher education system 
and would contribute each particular university to achieve the overall efficiency of its goals [Boychenko, 2017].

Galina Berehova discusses the main methodological vectors of the world outlook moulding of the person of the future in higher school required with time and defined with the state of the modern higher education in Ukraine, external and internal social and economic, political and cultural processes; Much attention is given to the constant necessity of elaboration of new concepts of the philosophy of education in connection with the always changing world and an urgent need to teach and educate new generations - people of future, able to solve global problems of the mankind all the time [Berehova, 2017].

Analysis shows that, starting from the culture of Antiquity, and up to the culture of Modernity, physical culture and physical education have played and continue to play an important role in human development. This question is identical to the level of the nation's health and the future of civilization, since only a healthy organism is capable of reproducing healthy offspring and guarantee the formation and development of a healthy psyche. Studies of the future largely ignore physical culture and are based on completely different postulates. This is an erroneous and deadlock solution, which will have to resort to physical culture and physical education. The role of the physical education teacher by no means becomes secondary. Quite the contrary, the struggle to increase life expectancy and its quality significantly expands the physical education teachers' perspectives in a changing world [Voitovska \& Tolochko, 2018].

The necessity of preparation of a specialist competitive in the labour market, competent, responsible, one who has excellent skills in his profession and oriented in related fields of activity capable of effective work in specialty at world level standards, ready for constant professional growth, social and professional mobility is a response to real needs and demands of our society, is a tendency and the main orienting point of modern educational programs in the world as well as in Ukraine.

Undeniable global leadership of the United States in the development of school, Olympic and professional sports, comprehensive state policies for encouraging citizens to improve motor activity, developed system of improvement of motor activity of the population, a wide range of educational areas for training of specialists in the sports industry in universities and colleges necessitate generalization of experience of this country and enable Ukrainian experts to review theoretical positions, achievements, problems, and to stimulate development of new approaches, programs and projects in this area [Medynskyi, 2016].

It was conducted comparative and pedagogical analysis of organization of professional preparation of teachers [Shandruk, 2012] and specialists in physical education and sports [Medynskyi, 2016] in the system of higher education in the United States of America with the purples to substantiate a possibility of creative use of the ideas of American experience in modernisation process of preparation of sports and physical culture specialists in Ukraine.

\section{Theoretical and methodological approaches of research}

The United States of America demonstrate consistently high performance of physical culture, health and sports industry and American experience of preparation of specialists in the field of physical education and sports is significant in this aspect. Effectiveness of functioning of sports industry in the United States is provided by skilled professionals whose training programs include formation of not only professional-oriented knowledge, skills 
and abilities but also skills of doing business, marketing, management, office work, etc., which Americans consider a prerequisite for gaining prestigious work for self-realisation, successful career, financial success and social stability. The variety of areas of preparation of sports industry professionals in the United States also include the professions of fitness instructor, sports trainer, health promotion specialist, recreational therapist, manager of physical education and sports.

American scientists Dominic Haydn-Davies [Haydn-Davies, 2010] studied educational and social components of physical education; Randall Hansen [Hansen, 2007] and Joseph Muscolino [Muscolino, 2014] studied the issues of kinesiology; Maggie Tourelle define kinesiology as one of the components of modern health care and disease prevention sector [Tourelle, 2013]; Susan Mansfield [Mansfield, 2010], Brian Sharkey [Sharkey, 2010] consider fitness as an integral part of human health, has a very subjective character, and is a significant component of a healthy lifestyle.

Christofer Delp study motor activity as a component of special fitness [Delp, 2006]. Wener Hoeger explores recreation, air training programming, park/natural resources, private/commercial tourism [Hoeger, 2012].

Uwe Pühse confirm that physical education is the most powerful tool for the development of sports culture of society [Pühse, 2005]. Susan Capel [Capel, 2012] and Mary Veal [Veal, 2011] study professional preparation of physical education teachers. Sh. Hoffman characterize components of a specialist in physical education Shirl Hoffman [Hoffman, 2013].

Richard Bailey studies the content and characteristics of physical education [Bailey, 2013]. Daryl Siedentop have developed a special system for evaluation of physical education programs [Siedentop, 1997]. Lynn Housner notes that the greatest challenge faced by physical education teachers in the United States is the creation of physical education programs that would meet the demands of modern society [Housner, 1996]. L. Kelly [Kelly, 2006] and Joseph Winnick [Winnick, 2011] analyze the standards for adapted physical education for training of disabled people.

To achieve the goal of our research such methods were used: comparative-historical method is used for comparison of socio-pedagogical facts, phenomena and results; component-structural method is used to distinguish main components of the system of professional preparation of specialists in physical education and sport, justification of guiding principles and functions; interpretive-analytical method is used for conceptual analysis of literary, documentary and other English-language sources with the use of interpretation, systematization, comparison and generalization; searching method is used for the formation of generalized conclusions, assessments, identification of rational and practical value in scientific developments of comparative pedagogy; statistical analysis is used to assess the state and dynamics of the development of the sphere of physical culture and sports in the modern world; prognostic method is used in order to apply knowledge of theory and practice of professional preparation of specialists in physical education and sports in the USA; to analyze the situation in the Ukrainian system of professional education and predict the prospects of extrapolation of American experience.

\section{Results and Discussion}

In order to determine perspective directions of implementation of American experience of professional study of specialists in physical education and sports in Ukraine we conducted 
interviews among teachers of higher educational institutions of Ukraine. Interviews covered 184 higher education instructors involved in preparation of specialists in physical culture and sports. The respondents were: 25 instructors of Vinnytsia Mykhailo Kotsiubynskyi State Pedagogical University; 27 instructors from the Faculty of Physical Education and the Faculty of Olympic and Professional Sport of Dnipropetrovsk State Institute of Physical Culture and Sports; 31 instructors of Lviv State University of Physical Culture; 29 instructors of the National Pedagogical Dragomanov University; 26 instructors from the Faculty of Physical Education of Ternopil Volodymyr Hnatyuk National Pedagogical University; 28 instructors from the Faculty of Physical Education of Chernihiv National Pedagogical University named after T.G. Shevchenko; 18 instructors from the Faculty of Physical Culture and Human Health of Yuriy Fedkovych Chernivtsi National University.

The questionnaire for instructors of higher education establishments in Ukraine was based on the data we received during the study of the problem of professional preparation of American specialists in physical education and sports in the United States of America (University of Central Arkansas, Stanford University, University of California, Minnesota State University, Indiana State University, Lamar University, The University of New Mexico, San Diego State University, California State University Long Beach, Oregon State University, Indiana University of Pennsylvania, San Jose State University, University at Buffalo, Temple University, The State University of New York, Pennsylvania State University), namely:

1. In the United States of America preparation of specialists in physical education and sports curricula are divided into three blocks: a block of disciplines of general education; a block of disciplines of the field of knowledge; a block of discipline of professional training / academic specialisation.

2. In the United States preparation of physical education and sports Bachelor's curricula comprise minimum 120 credits and are legally limited to maximum 130 credits.

3. In the United States the volume of blocks of disciplines in preparation of physical education and sports professionals' curricula are composed of: general education block - 40 credits; the field of knowledge block - 30 credits; academic specialisation block - 50 credits.

4. The block of general education disciplines is absolutely identical for all specialties within one educational institution in the United States.

5. Sequence of academic disciplines principle in the United States involves study of certain disciplines of academic specialisation only after mastering relevant disciplines from the blocks of general education and the field of knowledge disciplines.

6. Annual academic load in the United States is about 30 credits, corresponding to 10 three-credit disciplines.

7. The student's semester load in the USA is about 15 credits, corresponding to 15 hours of weekly classroom load.

8. Universities in the United States have a complete form of education and a partial form of education. Partial form of education involves training of less than 12 credits per semester, which leads to study duration increase.

9. Students studying in US universities at partial form of education must attend full-time classes in accordance with the number of semester credits.

10. There is a principle of constant loading of an educational institution at the United States universities, which involves additional spring and summer semesters for retaking and mastering additional academic disciplines. 
11. Despite fee-paying education in the United States, each student can receive financial support (scholarship) as sequence of his education quality (average score).

12. Universities in the United States require mastering of several disciplines at certain points.

13. The current success of students at US universities are fixed exclusively online.

14. Application of results of practice at US universities requires completion of paperwork and portfolio.

15. Curricula for preparation of specialists in physical education and sports in the United States of America do not provide writing a thesis and conducting a comprehensive assessment.

16. There is practice of obligatory membership of students in professional public organizations for completion of a Bachelor's Degree Program at the universities of the United States.

In preparation of future specialists in physical education and sports it was important for our research to clarify the issue of appropriateness of division of curriculum in higher education institutions into the content blocks (previously the division took place in cycles: humanitarian and socio-economic training, mathematical and natural science training; professional and practical training). Among 184 respondents: to construct three blocks (a block of disciplines of general education; a block of disciplines of the field of knowledge; a block of discipline of professional training) curricula consider $79.90 \%$ of instructors; such construction is unreasonable consider $5.43 \%$ of instructors; $14.67 \%$ of instructors were undecided. This result emphasizes importance and need for such a division (Figure 1). We also note that the result indirectly implies the need to restore the field of knowledge "Physical Culture. Sport."

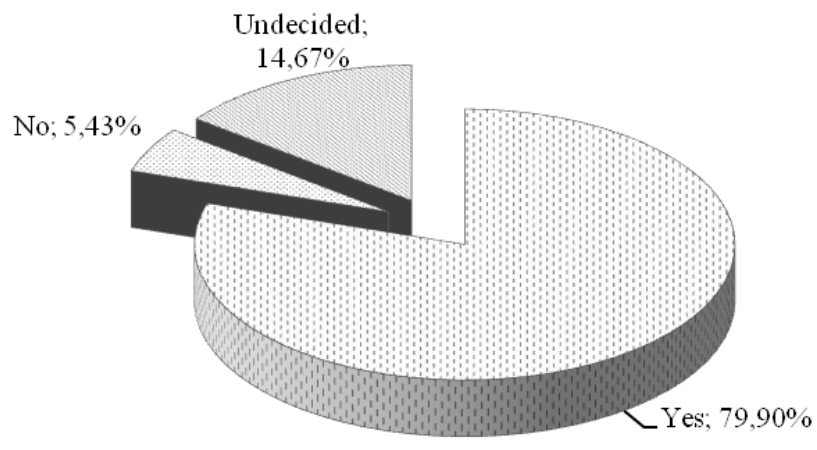

Fig.1. The results of the survey of higher education instructors on practicability of curricula division into three blocks.

The analysis of the answers of higher education instructors regarding appropriateness of quantitative regulation of maximum (130 credits) and minimal (120 credits) limits of student's academic load did not reveal a concrete vision of the issue. Answers were distributed as follows: yes $-33.15 \%$; no $-39.96 \%$; undecided - $29.89 \%$. Most likely this issue is not 
problematic since Ukrainian legislation clearly defines amount of credits (240 credits) for obtaining a Bachelor's Degree qualification level.

The results of the survey of instructors on practicability of ratio of credits among blocks of disciplines (general education - 40 credits, field of knowledge - 30 credits, academic specialization - 50 credits) give us the reason to claim that $54.89 \%$ of instructors support such division; $19.57 \%$ of instructors do not see the need for such division; $25,54 \%$ of instructors were undecided (Fig.2). Availability of such division not only indicates the necessity for certain correlation among blocks of disciplines in the curriculum but emphasizes the need in blocks of disciplines by type of orientation.

The obtained results of the questionnaires gave us reason to assert that it is expedient to train specialists in a higher educational institution with absolutely identical disciplines of the block of general education is considered by $76.63 \%$ of the interviewed instructors; inexpedient $-19.02 \%$ of the interviewed instructors; $4.35 \%$ of instructors were undecided. Obviously, such survey results should be taken into account.

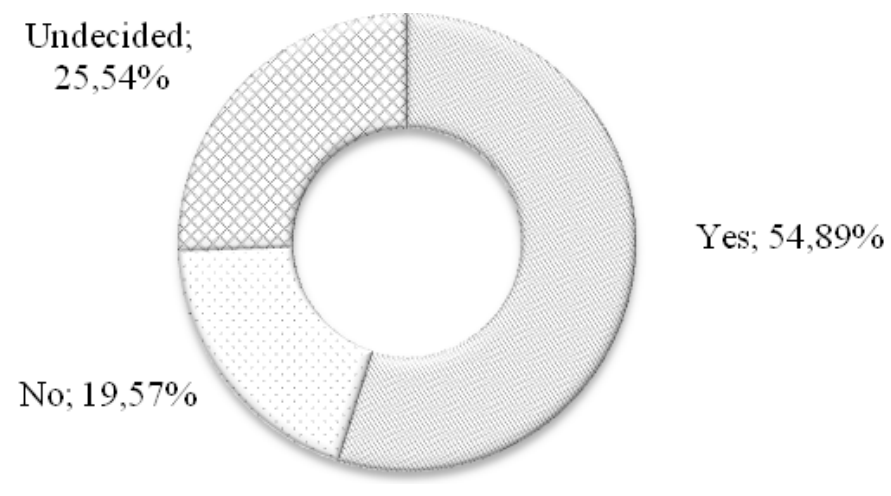

Fig.2. The results of the survey of higher education instructors on practicability of ratio of credits among blocks of disciplines

Among the interviewed instructors $89.67 \%$ consider it expedient to adhere to the chronological sequence in the study of disciplines of academic specialization (they are studied only after mastering corresponding disciplines from the blocks of disciplines of general education and disciplines of the field of knowledge); 4,35\% — do not consider it expedient; $5.98 \%$ of instructors were undecided. We share this point of view regarding the need for logic learning process construction.

Instructors' responses concerning academic load were divided in such a way that there is no clearly defined point of view (Fig.3). The survey of instructors regarding the annual academic load of 30 credits (corresponding to 10 three credit disciplines) showed the following results: this volume is sufficient - $29.35 \%$; insufficient - $28.80 \% ; 41.85 \%$ - undecided. 


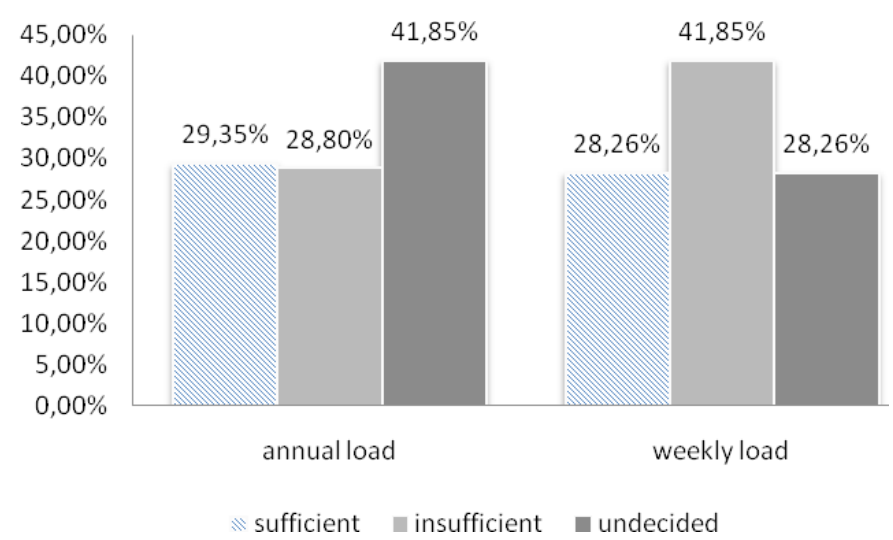

Fig.3. The results of the survey of higher education instructors on practicability of annual and weekly academic load.

The expediency of a clear relationship between educational credits and number of hours of weekly classroom load was supported by $36.41 \%$ of instructors; did not support - $35.33 \%$; $28.26 \%$ of instructors were undecided. Obviously, such uncertainty in the responses of the instructors is related to the significant difference between the American and the national systems for determining the amount of credits and the amount of academic load for obtaining a Bachelor's Degree. In addition, we would like to point out that in our opinion the American practice of a clear relationship between training credits and the number of hours of weekly classroom load is useful. This approach allows students of different educational institutions to receive the same amount of time for cooperation with highly skilled specialists (instructors).

Responses of the interviewed instructors regarding the expediency of a student's weekly academic load in 15 classroom sessions (15 credit semester load): support - $29.89 \%$ of instructors; do not support - 41.85\%; $28.26 \%$ of instructors were undecided.

According to the survey of higher education instructors it was established that $54.34 \%$ of the interviewed instructors found it expedient to have a partial form of education (with an annual volume of credits less than 12 but duration of study increases); do not consider it appropriate $-22.83 \%$ of instructors; $22.83 \%$ of instructors were undecided.

Analysis of the responses of higher education instructors on practicability of mastering full and partial forms of education the same number of hours of classroom load revealed that such a principle of organization of training is supported by $65.22 \%$ of instructors; is not supported by $19.56 \%$ of instructors; $15.22 \%$ of instructors were undecided. With such results, instructors confirm the need for the same amount of classroom training time for students of different forms of study.

The answers of the interviewed instructors regarding the expediency of having additional summer / winter training semesters of 1-3 weeks duration for elimination of "debts", acquisition of additional subjects by students and additional payment for such semesters do not allow us to interpret this problem categorically (Fig.4). $47.83 \%$ of the interviewed instructors support the idea of extra semesters; $36.95 \%$ of the interviewed instructors do not support; $15.22 \%$ of instructors were undecided. Let us note the characteristic feature although in general the idea of introducing additional summer / winter semester classes is recognized by instructors of higher educational institutions of Ukraine as practicable, the instructors of the National 
Pedagogical Dragomanov University $(69,97 \%$ versus $24,14 \%)$ and Dnipropetrovsk State Institute of Physical Culture and Sports (70.37\% versus $18.52 \%)$ do not consider it expedient.

The proposal on the expediency of extra payment for additional summer / winter semesters for retaking and mastering additional academic disciplines is supported by instructors of higher educational institutions of Ukraine almost unanimously: consider it appropriate - 70.11\%; consider it inappropriate $-18.48 \% ; 11.41 \%$ of instructors were undecided.

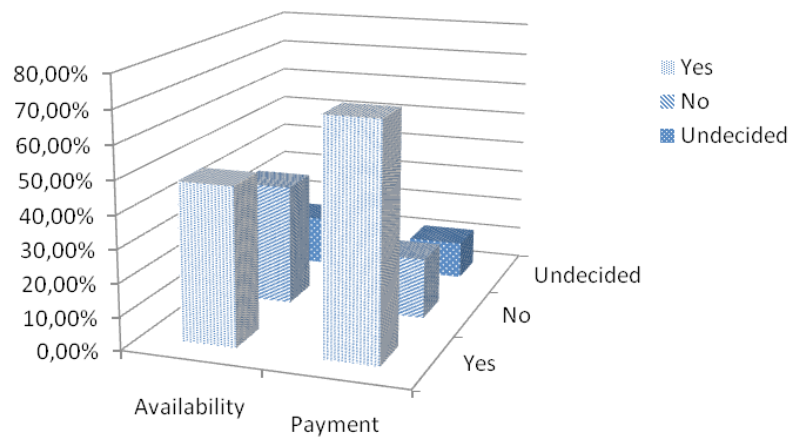

Fig.4. The results of the survey of higher education instructors on practicability of additional extra paid summer / winter semesters.

The questionnaire of higher educational institutions instructors made it possible to establish that $91.85 \%$ of instructors support practicability of providing scholarships to students solely on the basis of the results of their studies (regardless of the form of education: budget or fee paid); do not support - 5.98\%; 2,17\% of instructors were undecided. Thus, an absolute majority of higher education instructors believe that a scholarship should be an incentive for all students regardless of the form of study.

The obtained results of the questionnaires of instructors regarding practicability of conducting current selection of students during the study by establishing a minimum admission score for corresponding academic discipline testifies support of this type of current selection by $82.07 \%$ of instructors; do not support - 10.32\%; $7.61 \%$ of instructors were undecided.

Among the polled higher education instructors $64.67 \%$ supported practicability of online recording of current students' progress; determined as inappropriate $-23.92 \% ; 11.41 \%$ of instructors were undecided.

Analysis of the answers of higher education instructors on practicability of completion of paperwork and portfolio of all types of practice and writing a thesis and / or conducting a comprehensive assessment after completing a Bachelor's Degree Program is presented in Figure 5. We note that practicability of student's completion of paperwork of all types of practice and portfolio is supported by $82.61 \%$ of instructors; unsupported by $10.87 \%$ of instructors; $6.52 \%$ of instructors were undecided. 


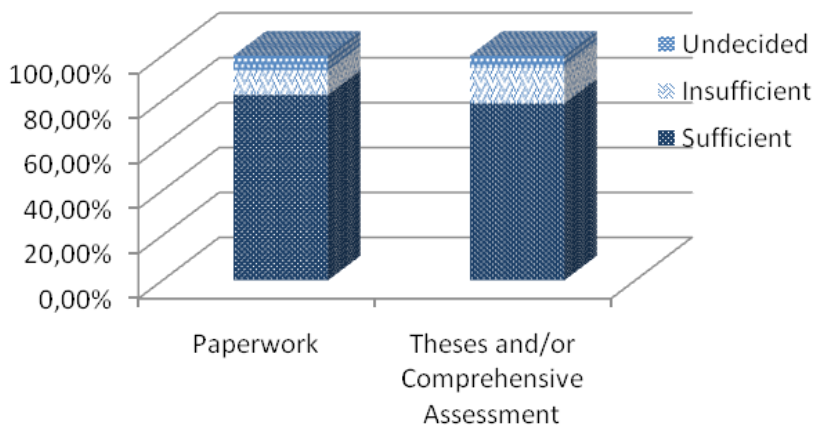

Fig.5. The results of the survey of higher education instructors on practicability of completion by students of paperwork of all types of practice and writing a thesis and / or conducting a comprehensive assessment.

It is considered appropriate to write a diploma thesis and / or to conduct a comprehensive assessment after completion of the Bachelor's Degree Program with $78.80 \%$ of the instructors (focusing on the need for a comprehensive assessment); considered inappropriate with 15.76\% of instructors; $5.43 \%$ of instructors were undecided.

Among the interviewed instructors, $51.63 \%$ consider practicable obligatory membership of students in professional public organizations for completion of the Bachelor's Degree Program; not practicable $-33.70 \% ; 14.67 \%$ of instructors were undecided.

\section{Conclusions}

By this qualifying experiment, we determined Ukrainian higher education instructors' level of perception of the components of practical organization of educational process at the US universities.

The survey on the theory and practice of professional training of physical education and sports specialists in the United States conducted for university instructors states that, in general, physical education and sports specialists - higher education instructors support: preparation of specialists in physical education and sports curricula should be divided into three blocks (a block of disciplines of general education; a block of disciplines of the field of knowledge; a block of discipline of professional training / academic specialisation); expediency of a certain ratio of credits among blocks of disciplines (general education - 40 credits; the field of knowledge - 30 credits; academic specialization - 50 credits); the block of general education disciplines should be absolutely identical for all specialties within one educational institution; sequence of academic disciplines principle should involve study of certain disciplines of academic specialisation only after mastering relevant disciplines from the blocks of general education and the field of knowledge disciplines; introduction of a partial form of education that involves training of less than 12 credits per semester with duration increase; students of partial form of education should attend full-time classes in accordance with the number of semester credits; additional paid summer / winter training semesters of 1-3 weeks duration for retaking and mastering additional academic disciplines by students; provision of scholarships to students solely on the basis of the results regardless the form of education (budget or fee paid); conducting the current selection of students by setting a minimum passing score for an 
academic discipline; fixation of current success of students exclusively online; requirement for requires completion of paperwork on all types of practice and professional portfolio; writing a thesis and / or conducting a comprehensive assessment after completing a Bachelor's Degree Program; membership of students in non-governmental professional public organizations for completion of a Bachelor's Degree Program.

The obtained data also determine possibility of using theory and practice of professional preparation of specialists in physical education and sports in the United States of America in higher educational establishments of Ukraine.

\section{[ㅁ] References}

Bailey Richard. Teaching Physical Education: A Handbook for Primary and Secondary School Teachers. London: Routledge, 2013.

Bazaluk, Oleg. The Theory of Education: "Those Who Transform the Universe" (New Book Announcement). Future Human Image. Volume 8, 2017: 9-13.

Berehova, Galina. Philosophy of Education: Main Methodological Vectors of Moulding the Person of the Future in Higher Education. Future Human Image. Volume 8, 2017: 1429.

Boychenko, Natalia. Counterfactuality of the Ethical Norms of Higher Education. Future Human Image. Volume 7, 2017: 28-35

Capel, Susan. Debates in subjects teaching. Ed. Susan Capel, Margaret Whitehead. London, 2012.

Delp, Christofer. Fitness for full-contact fighters. Berkeley, U.S, 2006.

Derzhavna natsionalna programa "Osvita" ("Ukraina XXI stolittia"). [State National Program "Education" (Ukraine XXI Century]. Access Mode. URL: http://zakon0.rada. gov.ua/laws/show/896-93-\%D0\%BF. (in Ukrainian).

Hansen, Randal. The Complete Idiot's Guide to Choosing a College Major. London, 2007.

Haydn-Davies, Dominik. Physical Education: Beyond the Curriculum. Leeds, 2010.

Hoffman, Shirl. Introduction to Kinesiology: Studying Physical Activity. Champaign, IL, 2013.

Housner, Lynn. Innovation and Change in Physical Education. Champaign, IL, 1996.

Kelly, Luke. Adapted Physical Education National Standards. Champaign, IL, 2006.

Mansfield, Susan. Go Facts Healthy Bodies, Fitness. London, 2010.

Medynskyi Serhii. Systema profesiynoii pidgotovky fakhivtsiv fizychnogo vykhovanniya e sportu u Spoluchennykh Shtatakh Ameryky [System of professional preparation of specialists of physical education and sorts in the Unitad States of America]. Chernivtsy, 2016. (in Ukrainian).

Muscolino, Joseph. Kinesiology: The Skeletal System and Muscle Function. Amsterdam, 2014. Natsionalna strategiya $z$ ozdorovchoi rukhovoi aktyvnosti na period do 2025 roku "Rukhova aktyvnist - zdoroviy sposib zhyttia - zdorova natsiya". [The National Strategy for Motor Rehabilitation in Ukraine up to 2025 "Motor activity — healthy lifestyle - healthy nation"], 2016. Access Mode. URL: http:/www.president.gov.ua/ documents/422016-19772. (in Ukrainian).

Natsionalna strategiya rozvytku osvity v Ukrayini na period do 2021 roku. [National Strategy of the Development of Education in Ukraine], 2013. Access Mode. URL: http://zakon2. rada.gov.ua/laws/ show/344/2013/page. (in Ukrainian). 
Pühse, Uwe. International Comparison of Physical Education: Concepts, Problems, Prospects. Aachen, Germany, 2005.

Shandruk, Svitlana. Tendenciyi profesijnoyi pidgotovky 'vchy 'teliv u USA. Kirovograd: ImeksLTD, 2012.

Sharkey, Brian. Fitness Illustrated. Champaign, IL, 2010.

Siedentop, Daryl. Making a Difference for Physical Education: What Professors and Practitioners Must Build Together. Journal of Physical Education, Recreation and Dance. 68 (4), 1997: 25-33.

Tourelle, Maggie. Principles of Kinesiology: What it Is, how it Works, and what it Can Do for You. London: Singing Dragon, 2013.

Veal, Mary. Analysis of Teaching and Learning in Physical Education. Burlington, MA, 2011.

Voitovska, Oksana and Svitlana Tolochko. Physical Education Teachers' Perspectives in a Changing World: From Future Studies to New Physical Culture. Philosophy and Cosmology. Volume 20, 2018: 139-145. DOI: 10.29202/phil-cosm/20/13

Hoeger, Wener. Fitness and Wellness. Boston, Massachusetts, 2012.

Winnick, Joseph. Adapted Physical Education and Sport. $5^{\text {th }}$ Ed. Champaign, IL, 2011.

Zakon Ukraiiny Pro Osvitu. [Law of Ukraine On Education]. Access Mode. URL: http:// zakon5.rada.gov.ua/laws/show/1060-12. (in Ukrainian).

Zakon Ukraiiny Pro fizychnu kulturu i sport. [Law of Ukraine On Physical Education and Sports]. Access Mode. URL: http://zakon5.rada.gov.ua/laws/show/3808-12 (in Ukrainian). 